\title{
A proposed Australian transition to an anhydrous ammonia fuel transport economy to replace liquid petroleum fuels
}

\author{
R. G. Boothroyd \\ Retired Chartered Engineer, Queensland, Australia
}

\begin{abstract}
Synthetically-manufactured ammonia fuel is proposed for distribution throughout Australia when we need to replace future diminishing petroleum resources. In the interim this would be derived from natural gas resources using the Haber Bosch process, leading to a progressive transition to $100 \%$ energy resourcing from sustainable electrical energy. Future 'stranded' energy resources are considered in remote rural areas in addition to large-scale fuel manufacture near urban areas. The integration of local transport fuel manufacture with increased rooftop photovoltaic air conditioning is examined for outback areas now suffering from excessive summer temperatures. Minimal effects on the existing electricity grid are expected. It is also proposed to replace the present long-distance commercial road transport trucking industry with a fleet of ammonia-inflated airships.
\end{abstract}

Keywords: sustainability, ammonia fuel, engine design, climate change, liquid transport fuels, airships.

\section{Introduction}

Concerns regarding anthropogenic climate change continue to apply pressure for using fuels without residues which increase the greenhouse effect [1]. This is combined with increasing concerns about the reliability of supply of conventional petroleum-based fuels of convenience.

Australia only consumes about $1 \%$ of the world's energy but per capita its transport costs are high, due mainly to the long travelling distances involved. Nevertheless the technology examined in this paper has possible application in other nations and is therefore of general interest. 
In a previous paper [2] proposals were suggested for coping with a sudden economic emergency resulting from world-wide shortages of petroleum products. This second paper is a sequel which outlines just one suggested way in which we can reorganise our energy requirements in a future world without fossil fuels. But in this case it differs from the strategies in [2] completely in that it is presumed that we will have overcome emergencies and have sufficient time to assess and compare various alternatives in detail. In this way we should be able to develop a well-designed infrastructure to accommodate our needs well into the future.

\section{Ammonia: fuel of the future?}

Anhydrous ammonia $\left(\mathrm{NH}_{3}\right)$ has long been considered to be an ideal fuel for a future world economy [3]. This is largely because it is a hydrogen carrier which can be liquefied to high density and carried in low pressure tanks similar to those now used for LPG. One well-established organisation has been active for many years in promoting the concept [4]. Even today, some optimistic predictions estimate $\mathrm{NH}_{3}$ to cost only $30 \%$ of the price of petroleum fuels, but opinions vary and, anyway there are complications and uncertainties in knowing how to use $\mathrm{NH}_{3}$ effectively.

Ammonia is one of the most widely used of all industrial chemicals. Currently it is made in bulk, mainly for use as an agricultural fertiliser, by the 100 year old Haber-Bosch process according to the exothermic reaction:

$$
\mathrm{N}_{2}+3 \mathrm{H}_{2}=2 \mathrm{NH}_{3}
$$

using atmospheric nitrogen and hydrogen derived from natural gas $\left(\mathrm{CH}_{4}\right)$ or, alternatively, some other carbon fuel. Although, at present, hydrogen derived from $\mathrm{CH}_{4}$ is cheaper than hydrogen from electrolysis of water, this situation would almost certainly be reversed in the context of this paper. The reaction in eqn. (1) is reversible and is carried out at about 200 atmospheres pressure and $450^{\circ} \mathrm{C}$ in the presence of an iron-based catalyst. Only about $15 \%$ of the reactants are converted in each pass through the reactor but recycling of the gases results in about $98 \%$ conversion overall. Necessarily, plants using the Haber-Bosch process must be very large to be economical. Extensive literature on the Haber-Bosch process is available, partly because eqn. (1) is ideal for teaching students about reaction kinetics, Le Chatelier's principle, engineering compromise etc.

Small scale manufacture of ammonia for local consumption is also possible using SSAS, a reversed form of ammonia fuel cell [4-7] using water, the atmosphere and solar/wind generated electricity. There is much present interest in developing this technology for 'stranded' sustainable energy resources in Alaska. This could also become of much interest in using similar 'stranded' energy resources in remote parts of Australia. Capital and running costs are estimated to be lower than the traditional Haber-Bosch process and in principle it is possible to scale the size of plant up or down to suit requirements, a facility which is not available with Haber-Bosch. 
The three most important means of using $\mathrm{NH}_{3}$ are internal combustion engines (Otto and Diesel cycles) and fuel cells. Although the viability of these technologies has been demonstrated, much more development work is needed for commercial application. $\mathrm{NH}_{3}$ is also suitable [8] for stationary gas turbines despite its low flammability qualities but the additional problems which would be experienced with using the fuel in civil aviation, while not insurmountable, appear to have precluded any serious studies in this area. Short haul, i.e. domestic flights, seem to present less difficulty in developing an ammonia-based aviation technology. Alternatively, recent tests on long-haul flights using biofuels have been encouraging and subject to environmental concerns from overuse, it seems reasonable to continue with this system because it involves minimum changes to present-day methods.

\section{Fuel cells}

\subsection{Unsuitability of PEM fuel cells}

Whereas pure hydrogen is readily used in fuel cells, the alkaline nature of ammonia poisons conventional PEM fuel cells. Even traces of $\mathrm{NH}_{3}$ will cause this $[3,9]$.

\subsection{Ammonia fuel cells}

$\mathrm{NH}_{3}$ can be used in fuel cells operating at high temperature [10] which is an unacceptable inconvenience in most applications. The slow start up and fragility of these cells are also adverse features.

Considerable research into developing fuel cells suited to ammonia fuel at lower temperature is underway in several research groups [4, 10-14] because of the convenience and efficiency of an ammonia fuel cell in transportation [3]. Progress in this area would be of much benefit in the light of the extent and cost of the work outlined in Appendix I.

\section{Internal combustion (IC) engines}

\subsection{Otto cycle machines}

The low flame speed and limited ignitability of ammonia requires special doping of the fuel $[9,15]$. Perhaps the easiest method, at least for normal running, is to dissociate ammonia in a heat exchanger in the engine's exhaust pipe. The resulting hydrogen in the $\mathrm{N}_{2} / \mathrm{H}_{2} / \mathrm{NH}_{3}$ gas mixture can be used to help with this problem. It seems surprising that there seems to be little general interest in thermal dissociation of ammonia by reversing eqn. (1) to obtain hydrogen as a fuel. 
Exhaust from these engines is not completely pollution free from $\mathrm{NO}_{\mathrm{x}}$ emissions but these can be mitigated, to some limited extent, with adaptation of some present-day techniques. Significant preliminary studies $[9,15,16]$ demonstrate the feasibility of the Otto cycle but much more development investment in this technology is required. Appendix I draws attention to the need for modern techniques to be applied in combustion chamber design.

\subsection{Diesel cycle machines}

Like petroleum-driven CI engines, using the ammonia Diesel cycle is usually more advantageous than using the Otto cycle. Special attention needs to be directed at problems associated with diesel injection of ammonia fuel which has a slow combustion flame speed [16]. Details in Appendix 1 show that there are technical solutions to overcoming this and other problems.

\section{Future commercial road transport}

It is considered that there is no future option but to discard completely the present-day technology of transporting goods by road using petroleum-based diesel-powered trucks. This is simply because the cost of fuel and the quantities needed would become prohibitive for long distance travel in Australia.

\subsection{The alternative of introducing airship technology}

It is suggested that the high cost and limitations associated with alternatives to road transport, such as solar-powered electric railways, can be avoided by developing a national transport network using airships. In this respect ammonia just happens to be an ideal resource to use.

\subsubsection{An advantageous night-time climate}

Most of Australia which is $50 \mathrm{~km}$ or more from the coast usually experiences a very low wind velocity at night. This is a characteristic expected of a large continental land mass, even though it is often the opposite of many observations in Western Europe. As might be expected, West Australia seems less advantaged than Eastern Australia in this respect.

This suggests that commercial transport by airships can be a night-time activity in order to minimise energy requirements. Occasionally, in Eastern Australia, there is a steady wind velocity in a NNW direction and vice-versa. However it seems unlikely that this would become a significant commercially-exploitable feature. 

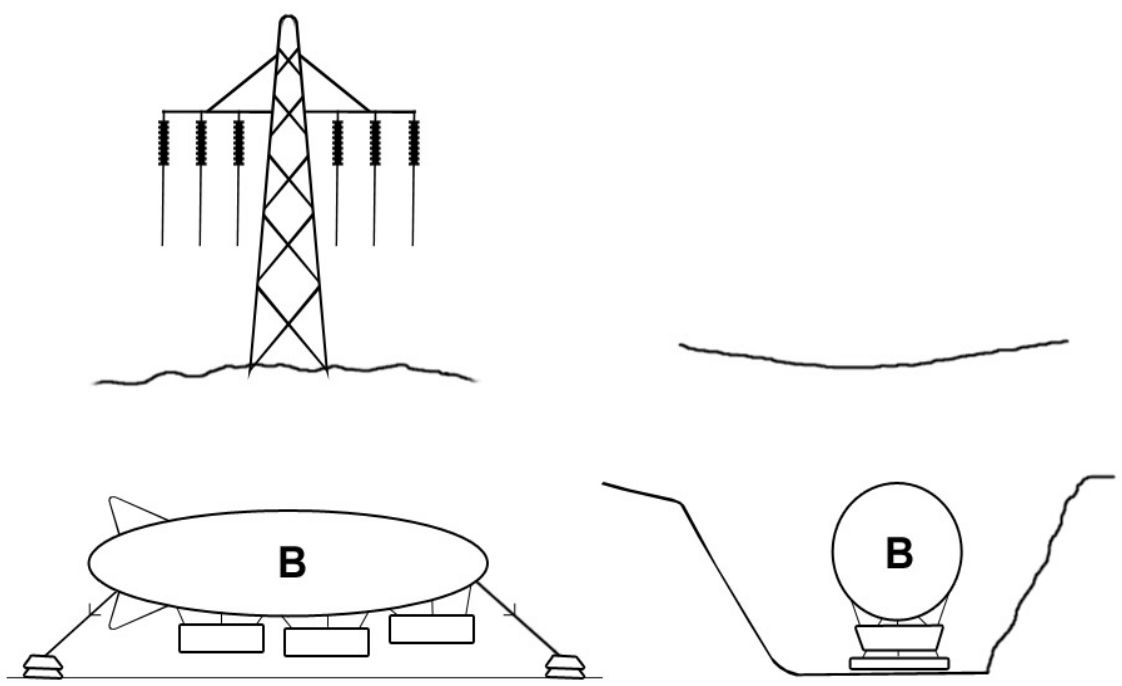

Figure 1: Two elevation views of a type B blimp using a disused railway cutting to pass under high voltage transmission lines. Safety considerations suggest that a better selection of the crossing point would take the blimp over the HV transmission line using a lightweight bridge structure.

\subsubsection{Two main types of airships}

The most attractive form of airship for normal commercial transport is the 'blimp'. Blimps are simple sausage-shaped gas bags with internal ballonets which can be inflated with a buoyant gas. They were used extensively in the Second World War as inexpensive barrage balloons. Their rigidity is limited by the lack of an internal stiffening structure but they are adequate for transport purposes if the externally-carried load can be distributed. These blimps would use ammonia as a buoyant gas at ambient temperature but ammonia has only about half the buoyancy effect of hydrogen or helium. Yet because of its low flammability, ammonia is a very safe buoyancy gas especially when compared with hydrogen which history has shown to be unacceptably dangerous. Ammonia is also inexpensive and readily available compared with helium. Ammonia also has another great advantage because it can be used easily in an automatic buoyancy control system [17]. This is because a small on-board compressor/heat exchanger system can be used to maintain buoyancy and trim on an airship by liquifying ammonia or gasifying it according to requirements. Ammonia is also a good refrigerant so that perishable goods can be transported over long distances. 


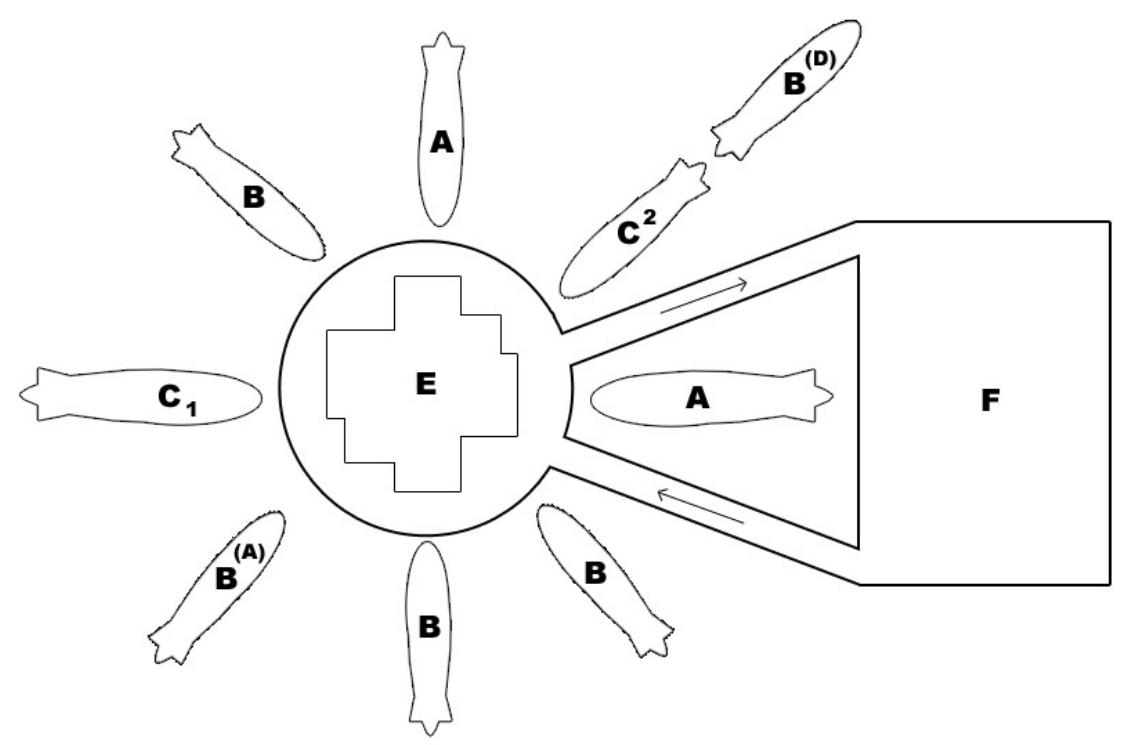

Figure 2: Plan view of transport terminal on the outskirts of a town. A wellchosen site would be in a slight depression surrounded by native trees. In this 8 blimp terminal, blimp $\mathrm{B}^{(\mathrm{A})}$ has just arrived and been docked and will be moved to vacant position $\mathrm{C}_{1}$. 3 type $\mathrm{B}$ blimps are loading/unloading. 2 type A blimps are also loading/unloading, Blimp $\mathrm{B}^{(\mathrm{D})}$ is departing leaving $\mathrm{C}^{2}$ for the next type $\mathrm{B}$ blimp to depart. $\mathrm{E}$ is the goods storage/administration building. $\mathrm{F}$ is the van/truck car park for local deliveries.

The less common (type A) blimp would have two gondola-mounted ammoniafuelled engines. These would probably be Otto cycle motors. Apart from their main task of propulsion and steering, they would be fitted with the small refrigerator/compressor and heat exchange equipment to use ammonia to trim the buoyancy of the blimp. The compressor unit would also be used for refrigeration of cargo when it is required. The liquid ammonia would be stored in the lightweight underside steel-tube frame used to suspend cargo. These type A blimps would be able to travel anywhere but are likely to be few in number and used mainly for local transport to isolated areas.

The more common, but similar (type B) blimp, illustrated in fig. 1, would be similar in size but lacking any propulsion system of its own. Type B blimps would be used for long distance interstate haulage. A type B blimp is shown in fig. 1 towed by an electric motor which grips a low voltage 3-phase transmission line tethered close to ground level. It is shown crossing below high voltage transmission lines which would be one of the hazards in using this system. A much safer, but slightly more expensive system, would be for the blimp to cross above the HV transmission lines. 
The type B haulage system would also connect more remote areas of Australia and, as is the case for railways, would probably only use a single track system with passing places. The fore and aft towing cables could also carry electrically superposed control signals because refrigeration and buoyancy trim equipment would also be used in type B blimps. Alternative design concepts would need carefully evaluated comparisons for a particular location.

There are some complicating features in the design of the type B haulage system. Good design of the buoyancy/trim control system could avoid the need for regenerative electricity production from the trailing blimp tether line. Both type A and type $\mathrm{B}$ blimps also need to be designed to act as $\mathrm{NH}_{3}$ fuel tankers.

On reaching their destination, tankers can be deflated and the $\mathrm{NH}_{3}$ stored in low pressure refrigerated tanks which dispense liquid fuel to pressurised tanks at ambient temperature for general use. The emptied type B tankers can be deflated on to the lightweight steel tube carrying frame and several empty tankers are then returned to the fuelling source as a single backload on another fully inflated type B blimp.

It is envisaged that all blimp transport systems would be fully automated and unmanned. Human labour would only be required for loading and unloading freight as illustrated in fig 2 .

The blimp network system proposed would achieve its main objectives. These are:

- Using liquid transport fuels made directly from solar/wind energy and renewable materials, or better still, in the case of type B blimps, using this renewably-generated electricity directly by eliminating the liquid fuel manufacturing stage completely.

- $\quad$ Exhaust products are nitrogen and water only which are non-polluting. If a poisonous ammonia cloud was released accidentally, buoyancy forces would quickly drive it upwards out of harm's way. Released ammonia would then combine with water vapour and atmospheric pollutants to return ultimately to the soil with rain as fertiliser. Accidental ammonia leaks are easily detected at very low concentration with the human nose but high concentrations are dangerous, especially to soft human tissue, partly because of the dehydration effect.

- $\quad \mathrm{NH}_{3}$ is not considered to be a greenhouse gas. It is emitted continuously in several natural processes. Horkheimer [17] even considers it acceptable to release ammonia to the environment to obtain sudden reduction in buoyancy.

- Ammonia fuel would become solar/wind-energy derived and a permanently sustainable resource. However if such a scheme was implemented, it would influence the design of the CST solar power stations [18] expected to be commonplace at this time. These would require larger molten salt storage facilities for increased night-time generation of solar electricity. This is not an issue presenting difficulty. 


\subsubsection{Using airships for improved transport of heavy industrial equipment}

Transporting heavy industrial equipment from the point of manufacture to the location of use is a severe problem in any country and Australia is no exception with regard to this difficulty.

Technical problems often arise from the need to divide large components into a manageable size whereas usually industrial equipment is best assembled as a whole unit at the point of manufacture.

Type A and B blimps are not suited for such tasks of heavy lifting. However there is no reason why the proposed network for blimps cannot be used by a much larger dirigible airship with internal structure designed for heavy loads. A buoyancy/ trim control system designed to a superior specification need impose no greater load on the 3 phase ground-based traction-cabling system, shown in fig. 1, than would be caused by a type B blimp. The network would inevitably require occasional strong tie-down points for adverse weather conditions experienced by type A and B blimps. A few of these can be made suitable for the much larger dirigibles used for heavy transport.

\section{Integration with universal air conditioning in a deteriorating climate}

Anthropogenic deterioration of the future world climate seems almost inevitable and is already resulting in summer temperatures exceeding $40^{\circ} \mathrm{C}$ in many inland parts of Australia which are not accustomed to such conditions. Consequently roof-top energised air conditioners are becoming essential for many homes and businesses. Rooftop photovoltaic systems are ideal as a 'stranded' power source for local air conditioning because they supply the largest air-conditioning power when it is most needed. Also these arrays offer the potential for local SSAS generation of ammonia fuel if connected to a small micro grid system to absorb surplus power in a SSAS system.

Grid connection is essential in accommodating the start-up surge current when refrigerant compressors switch on thermostatically. By contrast an isolated system away from a grid would need much more expensive power electronics equipment $[19,20]$ because PV arrays by themselves cannot usually accommodate the large switch-on surge current. The design of such systems differs slightly from presentday grid-connected systems operating with an input tariff and would need special consideration in power supply contracts.

\section{Social consequences}

Improvements in technology frequently cause reduction in employment opportunity, particularly for those in the workforce with limited skills. This applies to the above recommendation to replace Australian long-distance commercial trucking with a fully-automated 'blimp' transport network. There are more than $5 \times 10^{5}$ commercial vehicles of all types in Australia. Socially-objectionable as it may seem to find an alternative form of commercial transport, such a conclusion seems indisputable. Nevertheless it would be unethical to fail to address the social 
implications of adopting such a controversial suggestion. It seems that the best solution is to provide a public discussion facility [21] for all interested parties.

Many factors are involved and space precludes their discussion here. Ref. [22] covered many of them. Improved technology is usually beneficial in that it creates wealth. But the use of such wealth demands a social conscience.

In conclusion, it seems, at least to the present author, that finding technological improvements for our future world is a far easier task than instituting the necessary concomitant social reforms.

\section{Discussion}

This paper reviews just one possible solution to safeguarding a small nation's energy-supply future so that it can provide a reasonable measure of security for its descendants. Before reaching decisions alternative proposals will need similar assessment.

Contributions by technologists made towards a sustainable society seem so small compared with those of like-mind [23-28] in other disciplines. Nevertheless, between us we have the skills and understanding.

\section{Conclusions}

Ammonia as a fuel has several properties which are very attractive. However significant, but not insurmountable, problems need to be resolved for its efficient use in fuel cells and both Otto and Diesel cycle engines. Competing future fuels such as DME are also attractive [29] but lack the freedom from a $\mathrm{CO}_{2}$ emission footprint. Probably both $\mathrm{NH}_{3}$ and DME have a future in tomorrow's world. One factor of importance is that both these fuels have similar and dissimilar properties which are useful and they can be used with each other. Ammonia also has the advantage that it has natural buoyancy, no GHG effect, and can be manufactured in a wide range of plant size.

Although ammonia seems to be most useful in land-based transport, it presents greater difficulties in marine and aviation transport. Consequently the future is seen as not being completely $\mathrm{CO}_{2}$ free but one in which $\mathrm{GHG}$ emissions can be kept within easily manageable proportions.

It is concluded that technical solutions to our problems are often well within our grasp as we head towards a future which is largely of our own choosing.

\section{Appendix I: Ammonia fuelled Diesel engines and their role in future world commerce}

The slow flame front of diesel ignition using ammonia fuel can be improved with a variety of methods such as chemical doping, spark-ignition enhancement and increased compression ratio such as 30 to 1 . A recent study [15] of doping with 
DME yielded disappointing results despite indications that DME was a suitable chemical for this purpose. Nevertheless it has to be accepted that engines using new fuels such as DME or $\mathrm{NH}_{3}$ will require completely new design of the combustion processes and these considerations are very complicated especially in diesels.

We also need to be reminded of the much improved performance of both SI and CI petroleum-fuelled engines in the last few decades. These spectacular improvements in engine performance have arisen largely from extensive and continually improving research/development into combustion dynamics in the engine cylinder. It is inevitable, therefore, that new fuels such as $\mathrm{DME}$ or $\mathrm{NH}_{3}$ will require a similar programme of development. There is a huge available literature [30-33] relating to computer aided design of all aspects of combustion dynamics which includes detailed evaluation of fluid motion in the cylinder and aerosol science. This literature can, to a very large extent, be adapted for developing our use of new fuels. The technique used is to develop computer models of the cylinder combustion process progressively and refine them incrementally by comparing them with an identical change in experimental observations. Clearly the necessary work and its associated costs are very large. This is certainly a factor in the selection of the ammonia fuel economy for the future, because ammonia is a sustainable fuel and without significant influence on the climate. Therefore, hopefully, we should not need to repeat the expensive exercise of designing new engines, virtually from scratch, in the future.

Peering into the future, it seems reasonable to expect that today's computercontrolled, common rail, piezoelectric injection systems can be adapted for ammonia fuel after considerable research and development. This suggests the need to focus on world markets so that the investment load can be shared.

Ammonia and DME mixtures have a long history of usefulness and are compatible with each other. For example refrigerant $\mathrm{R} 723\left(60 \% \mathrm{NH}_{3}\right.$ to $40 \%$ DME) has improved lubrication properties compared with pure $\mathrm{NH}_{3}$ refrigerant. Alternatively an earlier technique [34] to avoid lubrication problems using elastomer sealing may have potential for use in diesel injectors for $\mathrm{NH}_{3}$ fuel because this is also compatible with the other likely requirement to keep ammonia injectors cooler than today's injectors which use straight diesel. Although injector design would depend on the size of the engine, it seems that even small injectors may need two, not one, piezoelectric valve systems if the easier example suggested below cannot be developed successfully. The first of these valves would also be controlled by the engine computer management system to open a vent, for most of the diesel cycle, releasing high pressure ammonia to 'bleed' and cool the injector stem through a drilling using the latent heat of evaporating ammonia. During injection this valve would be closed while the intermittent fuel injection through the other valve, possibly with spark assistance, is also operated by the engine management system according to present-day practice. Technical problems of using this system seem to be more severe as the engine size decreases but the problems associated with designing the really large diesels for large ships seem to be even more troublesome because of the much higher compression ratios desired with $\mathrm{NH}_{3}$. 


\section{Example of a promising approach}

Dual-fuel systems are commonplace today [35, 36]. For example using dimethyl ether and ammonia in different proportions under computerised engine management may well be a profitable line of investigation. As a mere speculation (as it appears that no such research/development has yet been attempted) a typical 3-4 litre turbocharged ammonia diesel might use stratified charge at 30:1 compression ratio. Ammonia is injected in the air intake, impinging on an exhaustheated hot-spot to achieve partial thermal dissociation according to:

$$
2 \mathrm{NH}_{3}=\mathrm{N}_{2}+3 \mathrm{H}_{2}
$$

Ignition is started by a pilot trace DME injector designed to give multiple small flame fronts in the stratified charge, Traces of unburnt ammonia can be designed to offset $\mathrm{NO}_{\mathrm{x}}$ emissions. According to ref. [36, pp. 58]: these complicated reactions can be summarised as:

$$
\begin{aligned}
& 4 \mathrm{NH}_{3}+4 \mathrm{NO}+\mathrm{O}_{2}=4 \mathrm{~N}_{2}+6 \mathrm{H}_{2} \mathrm{O}: 2 \mathrm{NH}_{3}+\mathrm{NO}+\mathrm{NO}_{2}=2 \mathrm{~N}_{2}+3 \mathrm{H}_{2} \mathrm{O} \text { and: } \\
& 4 \mathrm{NH}_{3}+2 \mathrm{NO}_{2}+\mathrm{O}_{2}=3 \mathrm{~N}_{2}+6 \mathrm{H}_{2} \mathrm{O}
\end{aligned}
$$

Clearly the reaction products are acceptable but the likely success of this approach remains an open question. The exhaust may (or may not according to the use of the engine) receive further catalytic treatment. EGR would definitely not be used to reduce $\mathrm{NO}_{\mathrm{x}}$ emissions in ammonia diesels.

All these actions would be programmed into the ECU of the motor including exhaust monitoring and control, When the engine speed falls to tick-over, the ECU cuts off ammonia flow and transfers all fuelling to the DME circuit

Such an engine, if it can be developed, would, in fact be less sophisticated in design than today's petroleum-fuelled diesels now used in small passenger cars with such high standards of reliability and performance.

\section{Marine application}

Ammonia may seem relatively unattractive as a fuel for merchant shipping because of severe weight penalties in large engines. This would result from higher compression ratios and the associated need for stronger engine cylinders. Also the fuel would probably need refrigerated storage.

Bearing in mind that coal will be the last fossil fuel to disappear, this may become an era when coal-slurry diesels will be used in large ships [37] possibly with DME to improve the fuel. There are effective $\mathrm{CO}_{2}$ mitigation techniques for Diesel exhaust which can only be used at sea, although these were not discussed in this earlier paper [37].

The size of the merchant shipping fleet seems likely to contract in the future as nearly all nations are likely to manufacture basic items for their own needs locally, probably under licence. This differs completely from the centralised manufacturing systems we use today which rely on relatively inexpensive 
transport in containers. However, if climate change forces nations to specialise more in the supply of rural products, the demand for merchant shipping could increase significantly. It is impossible to speculate with any accuracy without better predictions about our uncertain future.

\section{Appendix II: Nomenclature}

CFD Computerised fluid dynamics (gives full detail of the gas mixture motion in the cylinder during the cycle to allow calculations to be made from computer models)

CI Compression ignition, i.e. the Diesel cycle

DME Dimethyl ether $\left(\mathrm{CH}_{3}-\mathrm{O}-\mathrm{CH}_{3}\right)$

ECU Engine computer management system

EGR Exhaust gas recirculation used to reduce $\mathrm{NO}_{\mathrm{x}}$ emissions

GHG Greenhouse gas

LPG Liquid petroleum gas (mainly propane)

PEM Proton exchange membrane (fuel cell)

PV Photovoltaic (solar panel arrays)

SI Spark ignition Normally refers to the Otto cycle but in this paper spark enhancement may refer to a Diesel cycle

SSAS Solid state ammonia synthesis

\section{Acknowledgement}

Diagrams courtesy of www.pixelstardesign.com.

\section{References}

[1] Leggett, J., The Energy of Nations: Risk Blindness and the Road to Renaissance, Taylor and Francis, Hoboken, pp. 1-273, 2013.

[2] Boothroyd, R. G., Energy resources for transport: political apathy and neglect- an Australian experience, WIT Transactions on Ecology and the Environment, 190, pp. 637-650, 2014.

[3] Cheddie, D., Ammonia as a hydrogen source for fuel cells: a review, Chapter 13 in Hydrogen energy-challenges and perspectives, (Ed. Minic, D., pp. 333-362, Intech Open Science. (http://dx.doi.org/10.5772/47759) 2012.

[4] Solid State Ammonia Synthesis (SSAS), nhthree.com/ssas.html, 2013.

[5] Solid state ammonia synthesis (SSAS) pilot plant demonstration system for renewable energy, wleightyfoundation.org

[6] Chung-Yul, Y., Jong, H. J., Si, Y. J., Ji, H. Y., Ha-Na, J., Chan, H.H., Hyung, C. Y. \& Jong-Nam, K, Electrochemical ammonia synthesis from

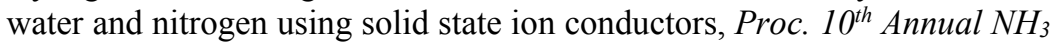
Fuel Conference, Sacramento, September 24, 2013. 
[7] Lan, R., Irvine, J.T.S. \& Tao, S., Synthesis of ammonia directly from air and water at ambient temperature and pressure, Scientific Reports, 3, Article 1145, (Nature.com, open access doi. 10.1038/srep01145), 2013.

[8] Evans, B., Using local green energy and ammonia to power gas turbine generators, Tenth Annual $\mathrm{NH}_{3}$ Conference, Sacramento, September 24, 2013.

[9] Saika, T., Nakamura M., Nokoya, T. \& Ishimatsu. S, Study of hydrogen supply system with ammonia fuel, JSME (Japan Society of Mechanical Engineers), 49 (1) Series B, pp. 78-83, 2006.

[10] Steele, B. C. H. \& Heinzel, A., Materials for fuel-cell technologies, Nature, 414, 15 November, pp. 345-352, 2001.

[11] Zamfirescu, C. \& Dincer, I., Using ammonia as a sustainable fuel, Journal of Power Sources, 185, pp. 459-465, 2008.

[12] Shohei, S., Hiroki, M., Toshiaki, M. \& Koichi, E, Fundamental studies on direct ammonia fuel cell employing anion exchange membrane, Journal of Power Sources, 208, pp. 257-262, 15 June, 2012.

[13] Ki, R. L., Dongsu, S., Seung, B.P.,\& Jong-min, H., A direct ammonium carbonate fuel cell with an anion exchange membrane, RSC Advances (Royal Society of Chemistry Advances) 4, pp. 5638-5641, 2014.

[14] Lan, R. \& Tao, S., Direct ammonia alkaline anion-exchange membrane fuel cells, Electrochemical and Solid State letters, 13 (8), B83-86, 2010.

[15] Ryu, K., Zacharakis-Jutz, G.\& Kong, S-C, Performance characteristics of compression-ignition engine using high concentration of ammonia mixed with dimethyl ether, Applied Energy, 113, pp. 488-499, 2014.

[16] Reiter, A., Combustion and emission characteristics of a compressionignition engine using dual ammonia-diesel fuel, thesis, paper 10560, pp. 1-96, Digital Repository@Iowa State University, 2009.

[17] Horkheimer, D. P., Ammonia- a solution for airships demanding rapid changes in net buoyancy, AIAA(American Institute of Aeronautics and Astronautics) $5^{\text {th }}$ Aviation Technology, Integration and Operations Conference, Arlington, VA, USA, (doi. 102514/6.2005-7393) 26-28 September, 2005.

[18] Wright, W. \& Hearps, P., (lead authors) et al., Zero Carbon Australia Stationary Energy Plan (2 ${ }^{\text {nd }}$ Edn), University of Melbourne Energy Research Institute, Australia, pp. 45-62, 2011.

[19] Kozmierowski, M. P., Control of converter fed induction motor drives in Wilamowski, B. M. \& Irwin, J. D., (Eds), Power Electronics and Motor Drives, ( ${ }^{\text {nd }}$ Edn) CRC Press (Taylor and Francis): Boca Raton Fl, USA, pp. 582-620, 2014.

[20] Femia, N., Petrone, G., Spagnuolo, G. \& Vitelli, M., Power Electronics and Control Techniques for maximum Energy Harvesting in Photovoltaic Systems, CRC/Taylor and Francis: Boca Raton Fl., pp. 1-355, 2013.

[21] Boothroyd, R. G., Proposed Australian transition to an anhydrous-fuel transport economy to replace liquid petroleum fuels with an examination of its social implications, (boothroyd.org) 2015. 
[22] Boothroyd, R. G., Urban planning for emergent technologies, new lifestyles and a changing environment, WIT Transactions on Ecology and the Environment, 179, pp. 93-108, 2013.

[23] Pettifor, A., The coming first world debt crisis, Palgrave/Macmillan: New York, pp. 1-190, 2006.

[24] Hamilton, C., Scorcher: the dirty politics of climate change Black. Inc: Victoria, Australia, pp, 1-266, 2007.

[25] Pearse, G., McKnight, D. \& Burton, B., Big Coal: Australia's dirtiest habit, University of New South Wales press: Sydney, pp. 1-257, 2013.

[26] Oreskes, N. \& Conway, E.M., Merchants of Doubt, Bloomsbury: New York, pp. 1-355, 2011.

[27] Pearse, G., Greenwash, Black Inc: Victoria, Australia, pp. 1-264, 2012.

[28] Hamilton, C., The Growth Fetish, Allen and Unwin: Sydney, pp. 1-262, 2003.

[29] Semelsberger, T. A., Borup, R.L.\& Greene, H. I., Dimethyl ether(DME) as an alternative fuel, Journal of Power Sources, 156 (2), pp. 497-511, 2006.

[30] Papetti, F., Golini, S., Maggiore, M., Succi, S., Gaillard, P. et.al. Internal combustion engine design on IBM platforms, IBM Systems Journal 31.4, pp. 774-782, 1992.

[31] Broach, A., Xandra, M., Gil, A \& Donaire, C., Computational study of the sensitivity to ignition characteristics of the resonance in a DI diesel engine combustion chamber, Engineering Computations, 24 (1), pp. 77-96, 2007.

[32] Saising, H., Golovitchev, V. \& Denbratt, I., Numerical analysis of combustion and emissions formation in a heavy duty DME engine, $S A E$ (Society of Automotive Engineers) technical paper 2012-01-0156, doi: 10.4271/2012-01-0156, 2012.

[33] Ge, H-W., Juneja, H., Shi, Y., Yang, S. \& Reitz, R. D., A two-zone multigrid model for SI engine combustion using detailed chemistry, Journal of Combustion, Article ID 201780, http://dx.doi.org/10.115/2010/201780, 2010.

[34] Boothroyd, R. G., Diesel injection of coal slurries and similar fuel, Speculations in Science and Technology, 1 (2), pp. 123-127, 1978.

[35] Deuchar, M., Operate your diesel vehicle on straight used vegetable oil, (4 $4^{\text {th }}$ Edn), www, vegiecars.com 2008.

[36] Kegl, B., Kegl, M. \& Pehan, S., Green Diesel Engines, Springer: Dordrecht, pp. 19-52, 2013.

[37] Boothroyd, R. G., Research/development suggestions related towards sustainable merchant shipping, paper 1067, General Proceedings WCTR, (12th world conference on transport research,) July 11-15, Lisbon, 2010. 